\title{
Management of oral myiasis: A rare entity
}

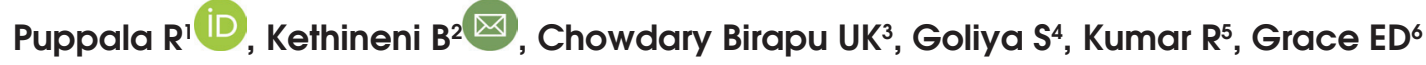

${ }^{1}$ Ravindar Puppala, Professor and Head; ${ }^{2}$ Balaji Kethineni, Professor; ${ }^{3}$ Uday Kumar Chowdary Birapu, Lecturer; ${ }^{4}$ Sneha Goliya, Lecturer; ${ }^{5}$ Raghavendra Kumar, Lecturer; ${ }^{6}$ Edara Lilly Grace, Lecturer; Department of Paedodontics and Preventive Dentistry, Sri Venkata Sai Institute of Dental Sciences, Mahabubnagar, Telangana, India.

\begin{abstract}
Myiasis is one of the foremost daunting parasitic infestations. Although pandemic, it is more often found in tropical and subtropical countries where poor hygiene, poor housing infrastructure, warm humid climate and proximity to domestic animals prevail. Mostly it occurs secondary to serious medical conditions such as cerebral palsy, cancerous lesions. Although many treatment protocols are available, the standard treatment focuses on antibiotic therapy concomitantly with mechanical removal of larvae and necrotic tissues. This is a case of intraoral myiasis in a twenty-year old female patient with cerebral palsy that was managed using the suffocation approach and mechanical debridement.
\end{abstract}

Key words: Cerebral palsy; Maggots infestation; Maggot; Myiasis.

\section{INTRODUCTION}

M yiasis is the infestation of living tissues caused by the larvae of fly species within the arthropod order Diptera. The word myiasis is derived from the Greek word "myia," which means fly".

It was first described by Laurence and F. W. Hope in 1909. Zumpt coined the term 'myiasis' in the year 1940 for the condition in which the dipterous larvae invade the human or other vertebrate animals and feed on host's dead or living tissue, liquid body substances, and ingested food for certain period of time ${ }^{2}$. The various species which

Access this article online

Website: www.jkmc.com.np

DOI: https://doi.org/10.3126/jkmc.v9i4.38096

HOW TO CITE

Puppala R, Kethineni B, Chowdary Birapu UK, Goliya S, Kumar R, Grace ED. Management of oral myiasis: A rare entity. J Kathmandu Med Coll. 2020;9(4):228-33.

Address for correspondence

Dr. Balaji Kethineni

Professor, Department of Paedodontics and Preventive Dentistry, Sri Venkata Sai Institute of Dental Sciences,

Mahabubnagar, Telangana, India.

E-mail: balajipgi@rediffmail.com

Copyright @ 2020 Journal of Kathmandu Medical College (JKMC) ISSN: 2019-1785 (Print), 2091-1793 (Online)

(i) (5) This work is licensed under a Creative Commons Attribution-Non Commercial 4.0 International License. cause myiasis include C. hominivorax, Oestrus ovis, Wohlfahrtia magnifica, Chrysomya bezziana, Hypoderma bovis, Cordylobia anthropophaga, Hypoderma tarandi, Calliphora vicina, Musca nebulo, Musca domesticus and Lucilia sericatab $b^{3-5}$. The various sites affected include head and neck region, skin, anus, and vagina'. The standard treatment focuses on antibiotic therapy concomitantly with mechanical removal of larvae and necrotic tissues ${ }^{6}$. Surgical debridement of the wound and extraction of larvae are most commonly done under local anaesthesia or general anaesthesia'. The suffocation approach forces aerobic larvae to surface in search of air where they can be removed with the aid of forceps or tweezers ${ }^{7}$. Due to the underlying systemic conditions and the prevailing condition of the patient, treatment under general anaesthesia was thought to be a risk factor for the patient. Hence, we tried the suffocation technique with turpentine oil.

\section{CASE REPORT}

A developmentally disabled bedridden 20-year-old female patient was brought to the department of Paediatric and Preventive Dentistry with the complaint of peeking of worms from the oral cavity for two days. The patient's mother informed that the patient was apparently asymptomatic two days back, later she noticed two worms coming out from the oral cavity.

Complete history revealed that patient was diagnosed with cerebral palsy since birth, followed by severe mental retardation. The developmental milestones were delayed 
and she developed spastic quadriplegia (cerebral palsy involving all the four limbs), kyphoscoliosis along with impairment of speech. Familial history revealed that there is no history of any consanguineous marriage. The patient had two siblings, who were healthy with no diagnosed disorders. The patient was completely dependent on her mother for her day-to-day activities including hygiene and nutrition.

General examination revealed severe wasting of all the forelimbs and pigmentation at the joints along with kyphoscoliosis. Extraoral examination revealed swelling in the infraorbital region on the left side, extending from lower border of eye to the ala of the nose and in the premaxillary region extending in between the nasolabial folds. The region over the swelling was normal, with no rise in temperature and no evidence of discolouration. Due to speech impairment, tenderness on palpation was not elicited by the patient. Intraoral examination revealed a full set of permanent teeth except the third molars, poor oral hygiene, class I molar relation with increased overjet and mouth breathing habit. A traumatic wound was noticed in the anterior maxillary region in the labial gingival tissue region extending from the right lateral incisor to the left canine. Gingival inflammation and recession were seen in the maxillary anterior teeth region along with peeling of the gingival tissue. Few maggots were seen peeking from inside of traumatic wound. Gentle lifting of the mucosa revealed multiple white coloured wiggly worms. Based upon all these features the patient was diagnosed by primary and accidental type of myiasis (Kettle's classification - 1984, Patton - 1922) ${ }^{8}$.

A suffocation technique with turpentine oil was used for removal of worms ${ }^{9-10}$. A gauge pack was prepared by adding a few drops of turpentine oil to it. The gauge was packed in the anterior maxillary vestibular region and kept in place for 10 to 15 minutes, after which the larvae were removed with the help of tweezers. No local anaesthesia was administered during the procedure. There was no evidence of bleeding from the traumatic wound as the larvae caused the necrosis of the underlying tissues.

The treatment was performed in two sittings and in each sitting approximately 7-8 larvae were removed with the help of tweezers. The second sitting was performed after three days as the approximate life cycle of the larvae is 50-60 hours ${ }^{11}$. The larvae were cylindrical in shape and creamy white in colour with tapered heads and high motility. The larvae were approximately $1.2 \mathrm{~cm}$ in length and in the head region a pair of dark hooks were evident. These larvae were preserved in 10\% formalin and sent to the department of pathology for identification, where they were identified as larvae of Musca domestica (common housefly).

Systemic antibiotics, syrup Augmentin - amoxicillin/ clavulanate potassium $(288 \mathrm{mg} / 5 \mathrm{ml})$ thrice daily, syrup Flagyl - Metronidazole $(400 \mathrm{mg} / 5 \mathrm{ml})$ twice daily, Pan 40 - Pantoprazole twice daily were prescribed for five days, along with Quadrajel ointment (chlorhexidine gluconate $1 \% \mathrm{~W} / \mathrm{W}$, lignocaine $2 \% \mathrm{~W} / \mathrm{W}$, metronidazole $1 \% \mathrm{~W} / \mathrm{W}$ ) for local application.

The parents were educated and motivated regarding the benefits of good personnel hygiene and nursing care. The closure of the traumatic wound was appreciated three days after using the turpentine oil. The patient was kept under review for one month and no recurrence was detected.

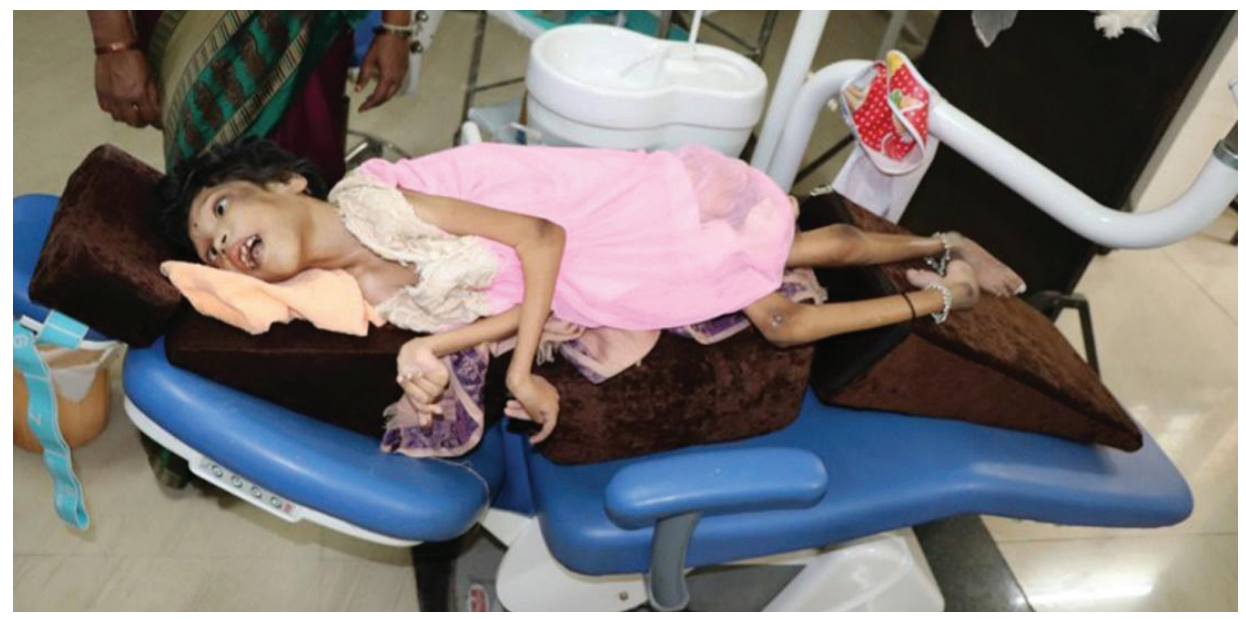

Figure 1: General examination. 


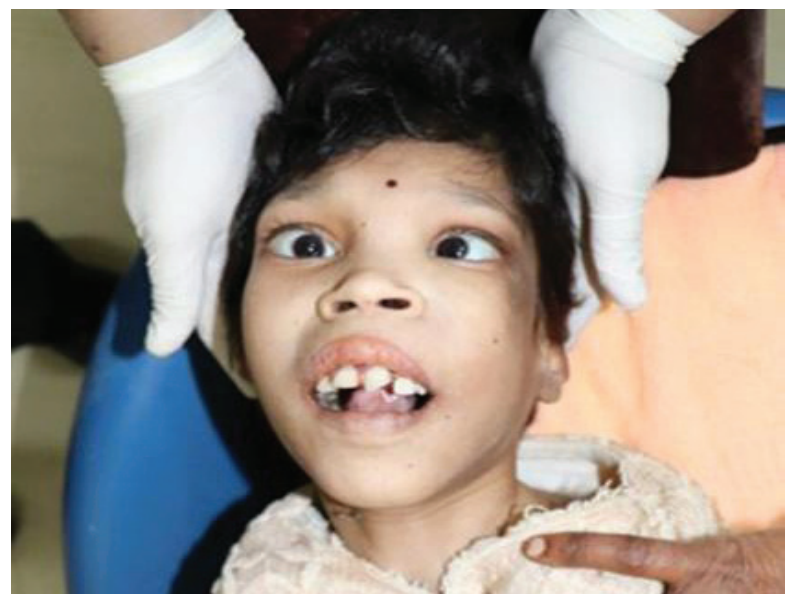

Figure 2: Frontal view.

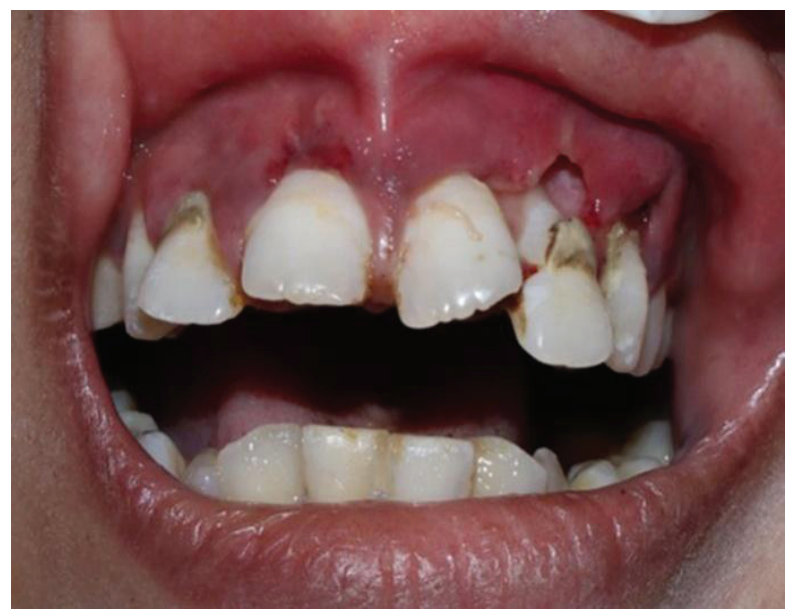

Figure 3: Intraoral photograph.

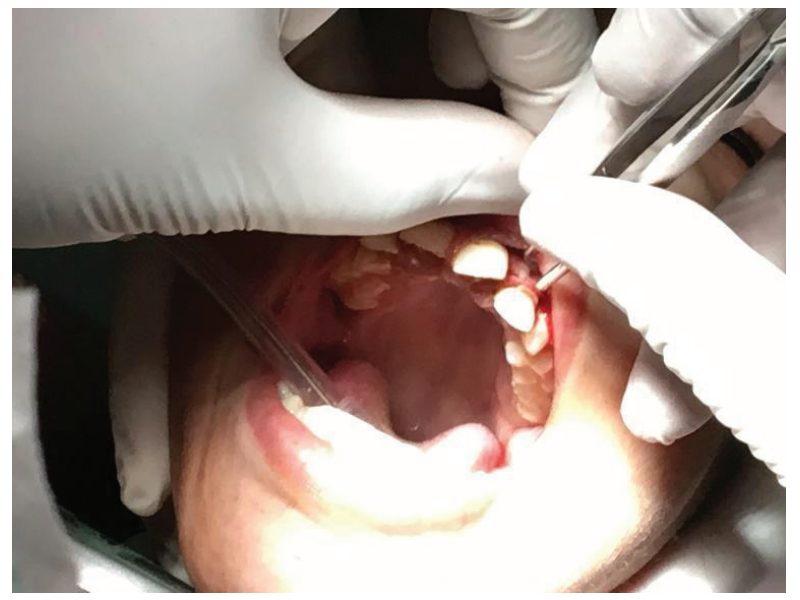

Figure 4: Removal of larvae.

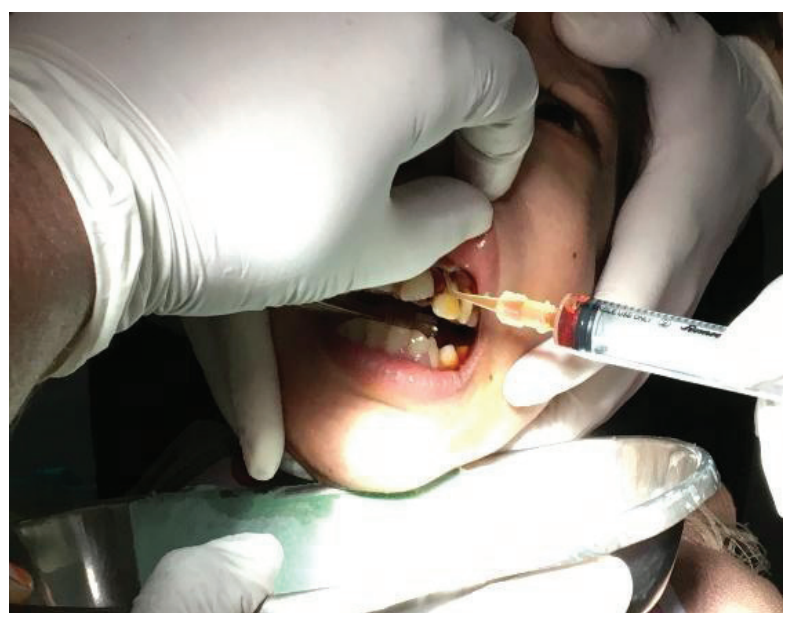

Figure 5: Mechanical debridement.

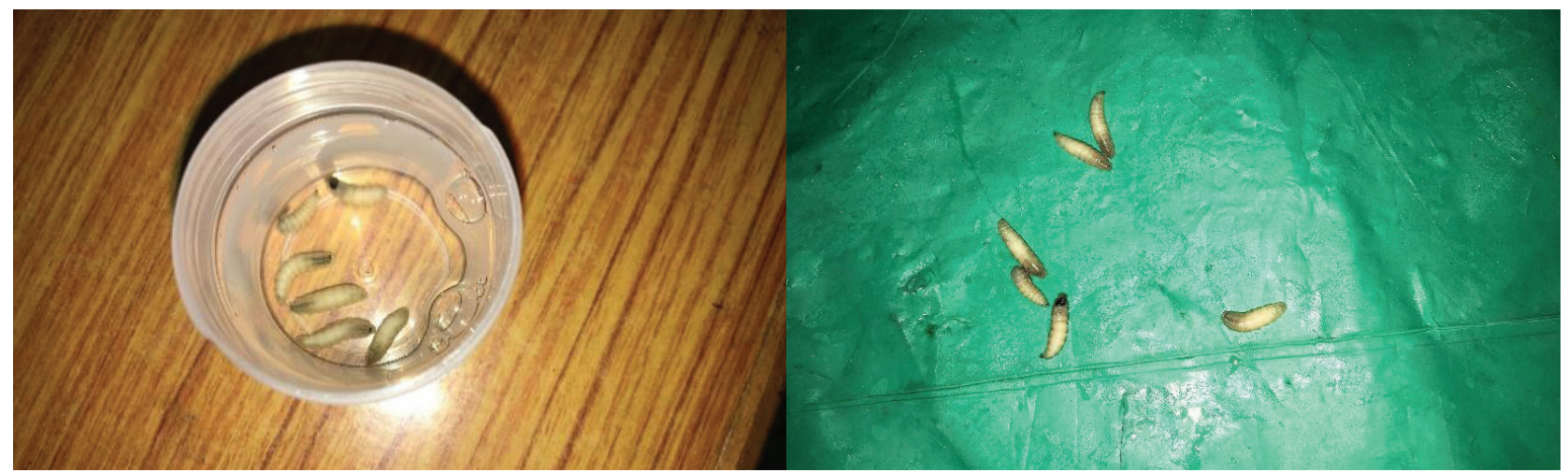

Figure 6: Larvae removed from wound.

\section{DISCUSSION}

Myiasis is usually among the five most common dermatologic conditions, accounting for $7.3 \%$ to $11 \%$ of cases $^{12}$. The prevalence of the disease is high in tropical and subtropical regions such as India, Tunisia, Brazil, and
Australia $^{3,13}$. Oral myiasis is a rare pathology in humans compared to other forms of myiasis, as the tissues of the oral cavity are not permanently exposed to the external environment ${ }^{14-16}$. Males are commonly affected than females $^{17}$. 
Aetiology: At least 86 different species of Diptera can infect man with larvae that invade skin and body cavities ${ }^{14,18}$. Myiasis is commonly caused by dipteran clade Calyptratae which consists of four families: Calliphoridae, Sarcophagidae, Oestridae and Muscoidea ${ }^{19}$.

Classification: Myiasis has been classified depending on various factors such as:

- location on the host body

- type of host parasite relationship

- type of tissues fed by larvae (clinical classification)

- condition of tissue involved

Based on location on the host body ${ }^{20}$ :

- Dermal, subdermal, nasopharyngeal, internal organs and urogenital.

Based on the type of host parasite relationship ${ }^{21}$ :

- Obligatory, facultative, or pseudomyiasis.

Clinical classification depending upon the type of tissues fed by larvae ${ }^{22}$ :

- Primary myiasis is caused by biophagous larvae feeding on living tissue and is rare in humans.

- Secondary myiasis caused by necrobiophagous flies feeding on dead tissue in a necrotic cavity or lesion.

Depending upon the condition of tissue involvement ${ }^{14}$ :

- Accidental (larvae ingested along with the food),

- Semi-specific (larvae laid on necrotic tissue in wounds), and

- Obligatory (larvae affecting the undamaged skin).

Clinical signs: Head and neck region, skin, anus and vagina are the sites most commonly affected. In the head and neck region, ears, eyes, oral cavity, nose, paranasal sinuses, lymph nodes, mastoid region and tracheostomy wounds are mostly affected ${ }^{1,13,23,24}$. The anterior part of the oral cavity is more commonly affected than the posterior because it is easily accessible to flies ${ }^{25-27}$ and the sites most commonly involved are the anterior segments of the maxillary and mandibular jaws and the palate ${ }^{4,14}$.

The various risk factors include poor oral hygiene, advanced age, low socio-economic status, medical comorbidities such as a history of craniomaxillofacial trauma and malignant tumors, ${ }^{28}$ cerebral palsy, ${ }^{21}$ neglected fractures, ${ }^{29}$ poor oral hygiene, ${ }^{30-31}$ mouth breathing, anterior open bite, ${ }^{32-33}$ cancrum oris, ${ }^{28}$ patient undergoing radiotherapy, ${ }^{34}$ person living in close proximity to animals ${ }^{18}$ and debilitated patient with neglect of nursing ${ }^{35}$.
The maggots cause infestation to the humans either by direct inoculation into wounds or through the ingestion of infected materials like meat. Flies which act as the intermediate host, lay approximately 500 eggs in the tissues. The larvae hatch in about eight to ten hours, after which they invade into the surrounding tissues and cause inflammation and discomfort to the patient due to the decomposition of the tissue caused by the proteolytic enzymes released by the surrounding bacteria ${ }^{36-37}$.

Larvae form a fibrous capsule and firmly adhere to it and this poses a difficulty in dissection during surgical procedure. As the larvae are photophobic; they tend to hide deep into the tissues for a suitable niche to develop into pupa ${ }^{38}$.

The burrowing of the larvae causes the separation of the mucoperiosteum from the bone creating a patent opening with induration of the marginal tissues and it appears as a dome shaped "warble". Infestation is mostly seen subcutaneously and it produces a furunculated or boil-like lesion, also called as "berne". Larvae position themselves with their heads down to expose their posterior spiracles to the air, which makes their respiration possible. The backward segmental hooks are useful for the anchoring of the larvae to the surrounding tissue ${ }^{14,39}$.

Treatment: Although a variety of treatments oppose the lack of a protocol, the standard treatment focuses on antibiotic therapy concomitantly with mechanical removal of larvae and necrotic tissues ${ }^{6}$. Surgical debridement of the wound and extraction of larvae are most commonly done under local anaesthesia or general anaesthesia'. The suffocation approach forces aerobic larvae to surface in search of air where they can be removed with the aid of forceps or tweezers?

Various substances like mineral oil, ether, oil of turpentine, ${ }^{9-10,14,29}$ chloroform, ${ }^{40}$ mercuric chloride, ethyl chloride, creosote, phenol, saline, calomel, gentian violet, white head varnish, olive oil, petroleum jelly, heavy oil, beeswax, nail polish, adhesive tape, butter, chewing gum, native tobacco leaf and iodoform can be used for the suffocation approach ${ }^{7,39,41-42}$. Broad spectrum antibiotics such as ampicillin, amoxicillin or metronidazole and topical use of nitrofurazone and ivermectin can be advocated along with multivitamin tablets for nutritional support ${ }^{22}$.

Ivermectin is administered as a single dose of 150-200 $\mu \mathrm{g} / \mathrm{kg}$ body weight. It is rapidly absorbed and reaches high blood concentrations within a relatively short 
period of time due to which the larvae are quickly expelled from the wound. Ribeiro et al. suggests the oral administration of ivermectin at a dose of up to $300 \mu \mathrm{g} /$ $\mathrm{kg}$ [that is, the patients weighing 40 to $60 \mathrm{~kg}$ : two tablets $(12 \mathrm{mg}$ ) and patients weighing 60 to $90 \mathrm{~kg}$ : three tablets (18 mg)] for three consecutive days, does not cause any intercurrence and eliminates all larvae in cavitary myiasis. Shinohara et al. and Gealh et al. recommend the use of ivermectin without debridement for patients with cutaneous myiasis $22,33,43$.

Secondary infection of the wound by bacteria is uncommon because of the bacteriostatic activity in the gut of larvae, which prevent the undesirable overgrowth of pyogenic bacteria ${ }^{44}$. In cases of secondary infection, systemic antibiotic therapy alone can be beneficial ${ }^{40,45}$.

Preventive strategies: Control measures of the fly population have emerged as an alternative strategy to prevent infestation. Basic sanitation and eradication of foci of adult fly proliferation are the first steps in the combat of this disease. Limiting myiasis directly relates to curbing the fly population by efficient waste disposal supplemented by spraying with an insecticide, providing

\section{REFERENCES}

1. de Arruda JAA, de Silva LVO, Silva PUJ, de Figueiredo EL, Callou G, Mesquita RA, et al. Head and neck myiasis: a case series and review of the literature. Oral Surg Oral Med Oral Pathol Oral Radiol. 2017 Nov 1;124(5):e249-56. [PubMed]

2. Laurence SM. Dipterous larvae infection. BMJ. 1909;9:88.

3. Hassona $Y$, Scully C, Aguida M, de Almeida OP. Flies and the mouth. J Investig Clin Dent. 2014 May;5(2):98-103. [DOI]

4. Droma EB, Wilamowski A, Schnur H, Yarom N, Scheuer E, Schwartz E. Oral myiasis: a case report and literature review. Oral Surg Oral Med Oral Pathol Oral Radiol Endod. 2007 Jan;103(1):92-6. [PubMed]

5. Sankari LS, Ramakrishnan, K. Oral myiasis caused by Chrysomya bezziana. J Oral Maxillofac Pathol. 2010 Jan-Jun; 14(1): 16-18. [DOI]

6. Villwock JA, Harris TM. Head and neck myiasis, cutaneous malignancy, and infection: a case series and review of the literature. J Emerg Med. 2014 Aug;47(2):e37-41. [PubMed]

7. Hubler WR, Rudolph AH, Dougherty EF. Dermal myiasis. Arch Dermatol. 1974 Jul 1;110(1):109-10. [DOI]

8. Natural History Museum. Introduction to myiasis. Available from: https://www.nhm.ac.uk/research- the patient with a physical barrier and good personnel and nursing care ${ }^{14,46}$.

Complications: The sequelae of myiasis include blindness, hearing loss, massive tissue destruction, salivary gland involvement, in addition to the development of an oroantral communication and considerable bone and soft tissue loss and even death may also occur.

Even though myiasis may be self-limiting and non-fatal in some cases, the patient and relatives report with huge psychological distress. Few larvae can destroy vital tissues, inducing serious or even life-threatening haemorrhage ${ }^{43}$.

Thus, establishment of the diagnosis and immediate treatment are necessary to interrupt progression of the disease and to prevent more devastating sequelae.

\section{ACKNOWLEDGEMENT}

The authors would like to acknowledge the Department of Paediatrics, Department of Cardiology, Department of Pathology, Sri Venkata Sai Medical College.

curation/scientific-resources/taxonomy-systematics/ myiasis-larvae/intro-myiasis/index.html [DOI]

9. Kumar P, Srikumar G. Oral myiasis in a maxillofacial trauma patient. Contemp Clin Dent 2012;3:202-4 [DOI]

10. Saravanan T, Mohan MA, Thinakaran M, Ahammed S. Oral myiasis..Indian J Palliat Care. 2015 Jan-Apr; 21(1): 92-94. [DOI]

11. Sunny B, Sulthana L, James A, Sivakumar T. Maggot Infestation: Various Treatment Modalities. J Amer College Clin Wound Specialists 2018 Mar 30;8(13):51-3. [PubMed]

12. Romano $C$, Albanese $G$, Gianni C. Emerging imported parasitoses in Italy. Eur J Dermatol. 2004 JanFeb;14(1):58-60. [PubMed]

13. Antunes AA, de Santana Santos T, Avelar RL, Neto EC, Neres BM, Laureano Filho JR. Oral and maxillofacial myiasis: a case series and literature review. Oral Surg Oral Med Oral Pathol Oral Radiol Endod. 2011 Dec;112(6):e81-5. [PubMed]

14. Kumar $P$, Singh $V$. Oral myiasis: case report and review of literature. Oral Maxillofac Surg. 2014 Mar;18(1):259. [PubMed]

15. Ali FM, Patil K, Kar S, Patil AA, Ahamed S. Oral myiasis affecting gingiva in a child patient: an uncommon case report. Case Rep Dent. 2016;2016:2197450. [DOI] 
16. Pereira T, Tamgadge AP, Chande MS, Bhalerao S, Tamgadge S. Oral myiasis. Contemp Clin Dent. 2010 Oct-Dec; 1(4): 275-6. [DOI]

17. Bhatt AP, Jayakrishnan AM. Oral myiasis: a case report. Int J Paediatr Dent. 2000 Mar;10(1):67-70. [PubMed]

18. Hakimi R, Yazdi I. Oral mucosa myiasis caused by Oestrus ovis. Arch Iran Med. July 2002 :5(3); 194-6. [DOI]

19. Jang M, Ryu SM, Kwon SC, Ha JO, Kim YH, Kim $\mathrm{DH}$, et al. A case of oral myiasis caused by Lucilia sericata (Diptera: Calliphoridae) in Korea. Korean J Parasitol. 2013 Feb;51(1):119-23. [PubMed]

20. Ogbalu OK, Achufusi TG, Adibe C. Incidence of multiple myiases in breasts of rural women and oral infection in infants from the human warble fly larvae in the humid Tropic-Niger Delta. Int J Dermatol. 2006 Sep;45(9):1069-70. [PubMed]

21. Rey L. Parasitologia. 2nd edition. Rio de Janeiro: Editora Guanabara Koogan; 1991.

22. Ribeiro FA, Pereira CS, Alves A, Marcon MA. Treatment of human cavitary myiasis with oral ivermectin. Rev Bras Otorrinolaringol. 2001;67,75561. [DOI]

23. Blejter J. Tracheostomy wound myiasis in a child: case report and review of the literature. Case Rep Pediatr. 2012; 2012: 317862. [PubMed]

24. Kumar SL, Manuel S, John TV, Sivan MP. Extensive gingival myiasis-Diagnosis, treatment, and prevention. J Oral Maxillofac Pathol. 2011 Sep;15(3):340-3. [PubMed]

25. Khan AA, Shah KM. Primary oral myiasis: a clinical presentation in cerebral palsy. Int J Case Rep Imag Title. 2013 Oct 25;4(2):95-8. [Full text]

26. Erfan F. Gingival myiasis caused by Diptera (sarcophaga). Oral Surg Oral Med Oral Pathol. 1980 Feb;49(2):148-50. [PubMed]

27. Gomez RS, Perdigão PF, Pimenta FJ, Leite AR, de Lacerda JT, Neto AC. Oral myiasis by screwworm Cochliomyia hominivorax. $\mathrm{Br} J$ Oral Maxillofac Surg. 2003 Apr;41(2):115-6. [PubMed]

28. Aguiar AM, Enwonwu CO, Pires FR. Noma (cancrum oris) associated with oral myiasis in an adult. Oral Dis. 2003 May;9(3):158-9. [PubMed]

29. Lata J, Kapila BK, Aggarwal P. Oral myiasis: a case report. Int. J. Oral Maxillofac Surg. 1996 Dec;25(6):455-6. [PubMed]

30. de Souza Barbosa T, SalvittiSá Rocha RA, Guirado CG, Rocha FJ, Gavião MB. Oral infection by Diptera larvae in children: a case report. Int J Dermatol. 2008 Jul;47(7):696-9. [PubMed]

31. Abdo EN, Sette-Dias AC, Comunian CR, Dutra CE,
Aguiar EG. Oral myiasis: A case report. Med Oral Patol Oral Cir Bucal. 2006 Mar 1;11(2):E130-1. PMID:16505789 [PubMed]

32. Rossi-Schneider T, Cherubini K, Yurgel LS, Salum F, Figueiredo MA. Oral myiasis: a case report. J Oral Sci. 2007 Mar;49(1):85-8. [PubMed]

33. Gealh WC, Ferreira GM, Farah GJ, Teodoro U, Camarini ET. Treatment of oral myiasis caused by Cochliomyiahominivorax: two cases treated with ivermectin. $\mathrm{Br}$ J Oral Maxillofac Surg. 2009 Jan 1;47(1):23-6. [PubMed]

34. Joo CY, Kim JB. Nosocomial submandibular infections with dipterous fly larvae. Korean J Parasitol. 2001 Sep;39(3):255-60. [PubMed]

35. Greenberg B. Two cases of human myiasis caused by Phaenicia sericata (Diptera: Calliphoridae) in Chicago area hospitals. J Med Entomol. 1984 Sep 28;21(5):615. [PubMed]

36. Srivastava R, Devi P, Thimmarasa VB, Jayadev S. Flies blown disease-Oral myiasis. Indian J Dent Res. 2011 Jul 1;22(4):615. [DOI]

37. Ramli R, Rahman RA. Oral myiasis: Case report. Malays J Med Sci. 2002 Jul; 9(2): 47-50. [PubMed]

38. Moshref M, Ansari G, Lotfi A. Oral gingival myiasis: a case report. Int J Tropic Med.2008;3(4):97-100. [DOI]

39. Felices RR, Ogbureke KU. Oral myiasis: report of case and review of management. J Oral Maxillofac Surg. 1996 Feb;54(2):219-20. [PubMed]

40. $\mathrm{Ng} \mathrm{KH}$, Yip KT, Choi $\mathrm{CH}$, Yeung $\mathrm{KH}$, Auyeung TW, Tsang AC, et al. A case of oral myiasis due to Chrysomya bezziana. Hong Kong Med J. 2003 Dec;9(6):454-6. [PubMed]

41. Wu CJ, Chang TS, Chu ST. Nasal myiasis in a bedridden patient and literature review. J Med Sci. 2012;32(1):39-41. [Full text]

42. Sikder M, Pradhan L, Ferdousi F, Parvin M. Oral myiasis: a case report. Bangladesh Journal of Medical Science.2011; 10(3):206-208. [DOI]

43. Shinohara EH, Martini MZ, Oliveira Neto HG, Takahashi A. Oral myiasis treated with ivermectin: case report. Braz Dent J. 2004;15(1):79-81. [PubMed]

44. MacNamara A, Durham S. Dermatobia hominis in the accident and emergency department:" I've got you under my skin". J Accid Emerg Med. 1997 May;14(3):179-80. [PubMed]

45. Al-Ismaily $M$, Scully $C$. Oral myiasis: report of two cases. Int J Paediatr Dent. 1995 Sep;5(3):177-9. [PubMed]

46. Singla V. Oral myiasis-a case report. J Oral Maxillofac Surg. 2013 Sep;71(9):1555.e1-4. [DOI] 